\title{
Innovative Social Media for Foreign Language Learning: A Review of Social Media Types and Their Effects
}

\author{
Fateme Jamshidian \\ English Department, Najafabad Branch, Islamic Azad University, Najafabad, Iran \\ Hadi Salehi (Corresponding Author) \\ English Department, Najafabad Branch, Islamic Azad University, Najafabad, Iran \\ Email: hadisalehi1358@yahoo.com
}

Received: $17 / 02 / 2020$

Accepted: $16 / 05 / 2020$

Published: 20/05/2020

Volume: 1 Issue: 1

How to cite this paper: Jamshidian, F. and Salehi, H. (2020), Innovative Social Media for Foreign Language Learning: A Review of Social Media Types and Their Effects. Journal of Critical Studies in Language and Literature, 1(1), 34-46 https://dx.doi.org/10.2525/jcsll.v.1n.1.2020 P.34

Copyright (C) 2020 by author(s) and Global Talent Academy Ltd. This work is licensed under the Creative Commons Attribution International License (CC BY 4.0).

http://creativecommons.org/licenses/by/4.0/

(c) (†)

\begin{abstract}
This review sets out to summarize studies that consist of research-based evidence indicating the effect of social media on language teaching and learning.We probed Information and Communication Technology (ICT), social media, different social networks, and language teaching and learning in academic databases such as ERIC, Springer, Taylor and Francis, Sciencedirect, ProQuest, Elsevier, Scopus, Wiley, and Google Scholar. From 350 studies related to the effects of ICT and social networks on language teaching and learning in the literature, 9o Iranian and international core papers were reviewed. This meticulous review showed that SNSs positively influence the process of the teaching and learning foreign language.
\end{abstract}

Keywords: Social Media, Social Networking, ICT, Information and Communication Technology, Social Networking Sites

\section{Introduction}

There is a growing body of literature recognizing the vital role of social media and social networking sites (SNSs) in language learning. According to Chen, Lin and Yuan (2017), social media refers to Web-based platforms in which individuals make and distribute messages and materials through communities and social networks. People use social media in their communication, they send and resend messages, and they create and distribute contents through social communication online. All messages and individuals' behaviors recorded by social media data. 'Social network site' is different from 'SNSs', 'Network' refers to representation of one's offline social network, 'networking' refers to relationship initiation between strangers (Ellison, 2007, as cited in Meng, Martinez, Holmstrom, Chung \& Cox, 2017). SNSs are instruments with the power to change the way individuals communicate with each other (Villafuerte \& Romero, 2017). They are forms of communication technology to communicate in an online environment including Facebook, Twitter, Myspace (Pegg, O'Donnell, Lala \& Barber, 2017), they are considered as fast-chatting phenomenon referring to all web-based services to create personal profile, publically to make and to display personal connections within a bounded system (Meng, Martinez, Holmstrom, Chung \& Cox, 2017). Based on Golonka, Bowles, Frank, Richardson and Freynik (2014), technology helps instructors change the way of their teaching and use different sources. Technology has positive effects and enhances motivation of students. Learners can have access to target language through technology; they interact with and receive feedback from each other. 
People prefer to use SNS in their communication rather than other technologies. SNS attracts attention of language researchers and becomes a subject of investigation for about 10 years. Meng, Martinez, Holmstrom, Chung, and Cox (2017) concluded that SNS is easy and flexible to improve listening therefore Spanish and Ecuadorian university students prefer to utilize YouTube and Google+ for language practices. Facebook and WhatsApp are motivators for reading, writing, and speaking practice in English.

\section{Methodology}

These days, more than100,000,000 users utilize the most popular social media including Baidu Tieba, Facebook, Gab, Google+, Myspace, Instagram, LinkedIn, Pinterest, Tumblr, Twitter, Viber, VK, Weibo, WhatsApp, Wikia, Snapchat, Friendster, and YouTube. Over the past decade, most research in language teaching and learning have emphasized the use of social media for language teaching and learning. This study focuses on qualitative and quantitative studies that provide research-based evidence on SNS's effect on language teaching and learning.

The present study has sought published papers related to Information and Communication Technology (ICT), social media, different social networks, SNS, and language teaching and learning in academic databases including ERIC, Springer, Taylor and Francis, Sciencedirect, ProQuest, Elsevier, Scopus, WILEY, and Google scholar. In total, 350 studies related to ICT, social networks, SNS, social media, language learning, and language teaching were found. SNSs which were not under investigation in this study included Baidu Tieba, Gab, Google+, Myspace, LinkedIn, Pinterest, Viber, VK, Weibo, Wikia, Snapchat, and Friendster. Moreover, the selected SNSs in this review did not cover all possible social media tools and SNS. Peripheral papers were excluded, and more attention was paid to those papers that investigated the effect of ICT tools including social media and social networks on language teaching and learning. This review was restricted to studies that focus on a single social media instead of multi-social media at once so that we selected 90 potentially core papers that met the criteria for evidence. These papers were related to language teaching and learning under the influence of social media including QQ, Skype, Facebook, Qzone, Reddit, YouTube, Twitter, Tumbler, Live Mocha, Edmodo, Storify, Instagram, Telegram, and WhatsApp. This review also compared the findings of Iranian studies with the findings of other researchers in other contexts in using social media. Table 1 in Appendix A provides a brief description and a list of SNSs, which were included in this study.

\section{Results}

The focus was on the role of some SNSs in the domain of the effect of ICT on language teaching and learning. This part of this review gave a summary of studies related to the effect of 14 social network sites on language teaching and learning. In the following paragraphs, we drew attention to the effect of social networks such as QQ, Skype, Facebook, Qzone, Reddit, YouTube, Twitter, Tumblr, Livemocha, Edmodo, Storify, Instagram, Telegram, Edmodo, Storify, Instagram, Telegram, and WhatsApp.

\section{1. $Q Q(1999)$}

QQ is one of Chinese social media tools. Not much attention has been paid to the effect, QQ has on English language teaching and learning. Various studies have given evidence on the role QQ plays in English language teaching and learning. The mentioned studies also state that learners and teachers show positive attitudes towards the use of QQ and its advantages in language teaching and learning.

In a survey study of QQ for creating seamless English language teaching Wei (2012) constructed a growing-up QQ group with 50 students. The author found that students' writing and reading skills had improved during four-months of instruction and interaction on a QQ platform. Students facilitated their language learning process when they collaborated and cooperated with their peers. Teacher helped students directly and dynamically at any time and place.

Few studies have examined the role of QQ in foreign language context. Li (2016) conducted a quasi-experimental study to examine effects of text-based QQ communication on medical college students' English writing. Thirty ESP students took part in this study and the results showed positive attitudes among the participants. Learners' writing performance was improved, their essay length increased and their errors decreased in terms of linguistic accuracy. They increasingly used compound and complex sentences in their writing. Because of real time interaction, learners preferred to write on QQ platform. In this study, students could get feedback from native speakers. QQ provided a relaxed environment for language learning.

3.2. Skype (2003)

Available evidence considering the effectiveness of Skype as SNS originates from mixed studies. Most quantitative research and qualitative studies of the effectiveness of Skype on language learning have investigated the effects of Skype on productive skills including speaking and writing. Warner and Chen (2017) argued, "Texts generated through SNS-mediated communication [Social network] can provide classroom opportunities for critical, stylistically sensitive reflection on the nature of talk in line with multi-literacies approaches" (p.121).

Warner and Chen (2017) claimed that

Framed within multi-literacies pedagogies, the great potential for SNS-mediated communication in contexts of language teaching and learning is perhaps not as a means of accessing speakers of a given language as if they 
were a clearly definable speech community whose ranks can be entered through technology nor as an alternative classroom management site, but rather as a means of exploring the complexities of speech communities and speech itself (p.134).

Based on constructivist theory, learners actively participated in the creation of knowledge in an interactive and effective process of learning (Shen \& Suwanthep, 2011, as cited in Yen, Hou, \& Chang, 2015). In 2013, Yen, et.al set out their mixed study of the effect of Skype on students' speaking errors in their pilot study. Forty-two participants took part in their study. The findings of their study led them to highlight a role-playing in Skype-based activities could smoothly decrease the errors in speaking skill. Yen, et.al (2015) said that synchronous online discussion through Skype and role-playing on this platform, improved participants' speaking and writing skills, Based on content analysis, peer to peer and self-correction made progress in productive skills.

Correa (2015) conducted a qualitative study of the effect of Skype ${ }^{\mathrm{TM}}$ conference calls on promoting English-speaking skills. The researcher found that 50 hours of online Skype conference during 8 weeks assisted four learners to practice their language skills. They also developed their social relationships with their friends, classmates, and even other people from different contexts. Skype conference calls improved learners' fluency in target language and helped them to use language in other contexts and environments rather than classrooms. The results of this study showed that Skype could improve speaking skills of EFL adult learners. In this study, learners had much more time to speak and to give their ideas about topic and course content via Skype. Skype chat promoted A2 adult learners' writing skills; it also increased learners' motivation. Moreover, it provided an opportunity to promote performance of teachers (Beltrans, 2005 as cited in Correa, 2015).

Terhune (2016) designed English language learning class through Skype to link teachers and learners. He stated that the participation increased whenever access to online teachers reminded during a 15 -week class. Students were enthusiastic about face-to-face English speaking over the internet for first weeks of running this project. Students experienced intense enjoyment when they interacted and communicated with the teachers in Philippines; however, students did not do their online lessons at their home.

Two studies focused on attitudes towards the use of Skype and obstacles in using Skype as a tool in distance and online learning. Blankenship and Kim (2012) investigated the use of situated learning in virtual environments made by teachers to experience authentic development beyond their current pedagogic knowledge. They pointed to positive potential use of virtual environments and pre-service teachers' positive attitudes towards it. Turhune (2013) mentioned lack of specific aim, relative autonomy, or feeling unease and uncomfortable in using social media for language learning as possible reasons why students did not participate actively in 15-week online course. Kotula (2016), in a quantitative survey study, investigated how teachers utilized Skype to teach online lessons. The researcher found Skype is an important tool in distant learning. The researcher also pointed to information technology (IT) infrastructure weaknesses, lack of some functions, and lack of a possibility to interact in a common space as restrictions of use of Skype in teaching.

3.3 Facebook (2004)

Several studies have documented the role of Facebook on foreign language teaching and learning. Since 2009, to the best of our knowledge, use of Facebook in language teaching and learning had been an object of research. In 2009, Blattner and Fiori highlighted the features of Facebook and described how it can be used for language learning. They pointed out features of Facebook like sending and receiving private messages, creating groups, offering application to attract chances for collaboration, assisting the class in involvement of key words and materials, setting up video conference for member, and joining groups to share similar interests in Facebook. In a mixed study, Kabilan, Ahmad and Abidin (2010) reported that learning English via Facebook was possible and students considered Facebook as an online environment facilitating English learning. The qualitative data analysis showed that Facebook influenced language skills, confidence, motivation, and attitudes. They concluded that teachers should use Facebook as a platform for socialization and learning, "there needs to be some form of structure and pre-determined learning outcomes so that students can focus on and be very clear about goals of language and/or learning" (p. 185). A number of authors have considered positive attitudes of learners towards use of Facebook in language learning (Suthiwartnatnarueput \& Wasanasomith, 2012; Eren, 2012 Yang, 2013; Razak, Saeed, \& Ahmad, 2013; Kanasin, 2014, as cited in Baföz, 2016).

According to Shih (2011), writing instruction and peer assessment via Facebook motivated learners and use of Facebook, also improved their English writing skills including organization, grammar, spelling, vocabulary and content. Saylag (2013) conducted an action research study to investigate the effect of Facebook on fostering interpersonal relations between EFL teachers and students through self-disclosure. Forty-seven EFL students participated in this study. The results revealed a significant relationship between self-disclosure of teacher through Facebook and students' eagerness to learn English. LantzAnderson, Vigmo and Bowen (2013) investigated how Facebook regarding as expanded spaces for language learning in school practices. In their exploratory case study, 60 students participated. They found that use of social networks like Facebook in schooling could begin expanded spaces.

Lantz-Anderson, Vigmo and Bowen (2013) stated that "such extended spaces where students can engage in language activities could be triggered by the students established communicative, collaborative practices that belong to their everyday use of language in social media" (p. 309). They also claimed that the impact of schooling is strong and the Facebook group cannot be considered as a vigorous space for language activities in line with young people's everyday interaction in SNSs. 
Aydin (2014) reported a need to investigate English as a foreign language using for interaction and communication between 121 Turkish EFL learners and teachers on Facebook. The focus of his study was on examining the level of learner's interaction with their teachers on Facebook. This study also determined the relationship between the level of their interaction and the demographic variables. He found that EFL learners behaved in a passive way regarding their interaction with their teachers because the teachers played the role of controllers and assessors not as organizers, counselors, and participants. He also emphasized the significant relationship between level of their interaction and variables consisting of age, gender, and year of study. He claimed that female learners, younger EFL learners, third-year and fourth-year students showed high level of interest in interacting with teachers and sending messages to them.

Buga, Căpeneaţă, Chirasnel, and Popa (2014) investigated the effect of Facebook on foreign language teaching and learning. They focused on two groups of students, one group in French and the other in English. Writing assignment was important in this study. They concluded that the use of Facebook could make a genuine context for communication. "Students, who had never written their homework before, started responding on Facebook to a variety of communicative assignments (Buga, Căpeneaţă, Chirasnel and Popa, 2014. p.1)".

In 2014, Binti, Shukor, and Noordin conducted a true experimental study to see the effects of Facebook collaborative writing groups on ESL undergraduates' writing performance. Thirty-three ESL students participated in this study. In their comparative study, the results showed that Facebook collaborative writing group indicated higher score as compared to faceto-face collaborative writing groups. They believed that Facebook created a meaningful environment in which learners could enjoy learning process.

Sun and Yang (2015) studied the use of platforms like Facebook and YouTube in EFL speaking class. Fourteen undergraduate students took part in this study. Based on the results of this case study, they concluded that use of Facebook and YouTube promoted students' self-confidence in speaking and increased idea organization, content development, speaking, pronunciation, vocabulary and grammar. Moreover, learners could access to target audience and make their own learning processes and strategies.

In 2015, Akbari, Pilot and Simons published a paper in which they investigated the differences between the effect of Facebook and a face-to-face classroom on English learning based on the self-determination. Forty Iranian PhD students participated in their quantitative quasi-experimental study. The results showed that Facebook helped Iranian PhD students learn English better than the face-to-face environment. Using Facebook in learning or teaching English made learners to feel more autonomous, competent and more socially active among other students.

Lai, Wang, Li and Hu (2016), in their survey study, investigated the effect of espoused cultural values of individuals on learner's voluntary technology adoption in informal learning context. Participants were 661 foreign language learners. The researchers used structural equation modeling. They found that "individual espoused cultural value orientations do influence language learners' self-directed use of technology for learning beyond the classroom, but this influence mainly comes from their direct effects on technology use rather than their moderating effects" (p.685). They also pointed to two cultural value orientations including long-term orientation and uncertainty avoidance that are involved in the optional assumption of technology for self-directed learning.

In their quantitative quasi-experimental study, Akbari, Naderi, Simons and Pilot (2016) investigated student engagement and foreign language learning through online social networks based on Astin's theory of student engagement. Forty PhD students participated in their study. They pointed out engagement as learning outcome happened in the Facebook group. Facebook group outperformed in TOEFL posttest than face-to-face group. The results of Facebook emphasized the fourth and fifth principles of Astin's theory related to involvement and engagement. They concluded that Facebook setting enhanced motivation and engagement.

In a quantitative survey study, Kasuma (2017) found that learners had positive perspectives, motivation and selfconfidence when they used Facebook for learning English language. Six hundred twenty-two participants with different ethnicity took part in this study. Their involvement with Facebook helped them learn English words and sentence structures. Based on the results, female Indian participants indicated highly attitudes towards Facebook.

Akbari, Simons, Pilot and Naderi (2017) drew attention to 83 Iranian PhD students' performance in a quasi-experimental study; they supported each other with much more feedback within Facebook rather than face-to-face classrooms. There was a positive relationship between corrective feedback and learning outcomes. They believed that amount of corrective feedback and criticism estimated outcome of learning within Facebook group. In a mixed study, Faryadi (2017) used triangulation methods to investigate the effect of Facebook on learning English. Nine-hundred Malaysia students participated in this study. The author concluded that Facebook as a platform assisted learners to improve English proficiency; Facebook also increased their vocabulary knowledge and terminology. Almost all the learners regarded Facebook as a motivator of language learning and as a tool for improving critical learning and increasing confidence.

Özdemir (2017) conducted a mixed study to see the effect of Facebook on intercultural communicative effectiveness (ICE). Participants were 25 female and 15 male students in this study. The author concluded that class discussion group received higher ICE scores as compared to Facebook group. Moreover, he pointed to positive attitudes and feelings of students when they used Facebook for developing ICE. They indicated positive attitudes towards intercultural instruction.

According to Özdemir (2017), some studies provided important insights into the effect of Facebook on improving both language skills and cross-cultural understanding (Hirotani and Fuji, 2015); providing opportunities for promoting intercultural competence (Jin,2015); simplifying intercultural awareness and language learning experience of both linguistics 
and intercultural gains (Bray \& Iswanti, 2013). Based on mixed evidence, Facebook has played a significant role in language proficiency, vocabulary learning, communication, writing and speaking performance.

3.4 Qzone (2005)

Few studies have investigated the effect of Qzone on English language teaching and learning Xianwei, Asmawi and Samuel (2017), in their qualitative case study, investigated use of Qzone Blogs for critical peer feedback with critical thinking for business English writing. Six Chinese undergraduates participated in this study. They used three semi-structured interviews and business English writing assignments to collect data. Writing assignments were analyzed by critical peer feedback. They found that Qzone blog had high efficiency of critical peer feedback and had popularity among students. It was unrestricted in place and time; it provided the opportunities for learning through mobile, transferring messages, privacy protection, and comfortable ICT platform for online critical peer feedback. They also pointed to character limitation as weakness of Qzone.

In a qualitative study, Xianwei, Asmawi and Samuel (2016) examined how Qzone weblog influenced critical peer feedback in an online environment. The results showed that Qzone is a proper type of weblog for online critical peer feedback. They believed that Qzone had more powerful special features including1) combination with IM software and weblog, 2) connection to SNS and distributing need, 3) user friendly, 4) multimedia weblog with image, text, audio, video and flash. The results of QRS Nvivo 8 showed that text-based feedback, various emoticons, anonymous feedback, quotation for mutual feedback and instant message notice were Qzone characteristics for critical peer feedback. Qzone was a proper platform for Chinese students in china.

3.5 Reddit (2005)

A search of the literature revealed very few studies that investigated the role of Reddit in language teaching and learning However, York and Stiller (2013) conducted a mixed study to scrutinize the effect of Reddit on receiving feedback from native English speakers and providing themes for cross-cultural communication. They concluded that students enjoyed learning. They were exposed to an authentic English-speaking; they could use language more than before.

3.6 YouTube (2006)

Recent developments in use of technology have highlighted the need to investigate effect of these technologies on learning and teaching English. In a qualitative study, Sun (2014) investigated how Taiwanese pre-service teachers used YouTube technology into their microteaching videos on YouTube. Twelve participants took part in this study. The results showed that teachers used different styles and approaches. They indicated positive perspectives towards use of YouTube in their teaching; they faced with technical difficulty in creating microteaching videos. Some factors consisting of changing motivation, sources of anxiety, focusing on visuals and personal appearance and lack of interaction and feedback could effect on sending, receiving, and quality of microteaching lessons.

In a quantitative experimental study, Kuo (2009) compared three experimental group performances to see the impact of YouTube listening/viewing activities on Taiwanese EFL learners' listening comprehension. The results pointed to the important role of You Tube activity played in improving listening comprehension; moreover, numbers of clips were used in each group predicted differences at group performance. She concluded that use of YouTube made an opportunity to speak with authentic native speaker that could be useful for language learning.

Alwehaibi (2015) carried out the experimental study to find the effect of use of YouTube on language classroom. The author concluded that YouTube could have influence on increasing content learning of EFL college students. The researcher considered YouTube as an important teaching resource. Albaddi (2013) conducted a survey study to explore English teachers' attitudes towards YouTube and their familiarity with this teaching tool. The sample size was 124 . The results of his study showed positives attitudes and eagerness to use this instrument. However, there was no correspondence between this enthusiastic feeling and familiarity with use of YouTube. Two effective factors for this lack of correspondence were lack of computer skills related to computer assisted language learning and the need for training use of technology.

In a qualitative study on 84 participants, Chen (2013) investigate students' motivation and autonomous in learning and the role of teacher in use of YouTube in a classroom. The author concluded that YouTube make students to become more independent and the teacher should control their autonomy and confidence in learning process.

3.7 Twitter (2006)

In a qualitative case study, Sekiguchi (2012) reported that learning environment on Twitter kept regular learning routines and motivation; it also increased their self-regulated learning. Hattem and Lomicka (2016) did a review study of a critical analysis of Twitter research in language learning from 2009 to 2016. They reported the potential of microblogging to increase the degree of communication and interaction between students and native speakers; it also persuaded noticing and meaning negotiation. They also pointed to results indicating use of Twitter diversely in language educational settings, levels and different tasks. Based on the analysis of 17 studies, the sample sizes of studies were 10 and 50 . These studies focused on writing, grammar, specialized vocabulary, pronunciation, pragmatics, and competences. As they stated:

One thread that emerged from the research on skill and competence development suggests Twitter may facilitate noticing by increasing the saliency of the target structures. The researchers helped students notice. These features through tweets containing explicit instruction and enhanced input in the form of capitalization of stressed syllables, occasional translations, and authentic examples Embedded as multimedia files and links in the tweets. (p.16) 
In their review study, Hattem and Lomicka (2016) examined the use of Tweeter for corrective feedback on writing, reducing anxiety, increasing confidence (de Larreta-Azelain, 2013); involvement in peer to peer, more positive feedback than corrective feedback, noticing mistakes and corrective feedback (Perez-Sabaterand Montero-Fleta, 2015), involvement in negotiation meaning (Antenos-Corforti, 2009; Hattem, 2012).

In his quantitative experimental study, Al-Dawood (2013) concluded that Micro-Blogging on Twitter has impact on increasing the vocabulary in female EFL students. Moreover, he emphasized the integration of social networking instruments into the foreign language learning. He also pointed to the positive attitudes of students towards twitter. Lord and Lomicka (2014), in a qualitative study, argued the effect of twitter in a graduate seminar on language teaching methodology. The sample size was 80 teachers. Based on discourse analysis of the tweets content, the author found that microblogging tasks make individuals to create an online community of practice in which they can learn, share and reflect.

In their qualitative pilot study, Roy, Brine and Murasawa (2016) focused on using Twitter as tool for English note-taking applications in a foreign language-learning context. The sample size was 25 participants. They concluded that the majority of students were relaxed with the tasks; they faced with difficulty with certain tasks and features.

3.8 Tumbler (2007)

In contrast to Facebook, limited empirical evidence exists regarding the effect of Tumblr on language teaching and learning. Yunus and Salehi (2012) investigated teacher trainees' perceptions on the role of Tumblr as an instrument to promote students' writing skills. They concluded that two thirds of the respondents considered Tumblr as a useful instrument in teaching writing skills. Features of Tumblr enhanced students' motivation and assisted them to receive feedbacks. Learners could promote their writing skills by brainstorming, generating and sharing ideas. Two limitations of using Tumblr were lack of technology knowledge and no access to internet in all places.

3.9 Livemocha (2007)

Search of the literature uncovered three studies with data on the effectiveness of Livemocha on language learning processes. About 4174 Livemocha users participated in a survey and 20 of them took part in an interview. In their mixed study, Lin, Warschauer and Blake (2016) found positive attitudes towards usage and progress language learning through social networks such as Livemocha. Moreover, the results revealed two problems including lack of long-term continuous and lack of accuracy.

Jee and Park (2009) described Livemocha as system in which learners could interact with other nonnative speakers and native speakers; they could send and receive peer feedback. Livemocha increased autonomy and motivation by checking their progress regularly. In a qualitative case study, Brick (2013) studied seven students to investigate use of social networking sites through learning languages. The author pointed to positive and negative reaction of students when they used Livemocha during three months. Negative points referred to complete lack of explicit grammar teaching on Livemoca, materials seemed to be quite poor and word list were very cheap to produce. Livemocha offered 'Premium content' and 'opportunity of interaction with native speakers'. Two benefits of livemocha were synchronous and asynchronous interaction with native speakers and immediate peer feedback available.

3.10 Edmodo (2008)

Empirical studies regarding the use of Edmodo in language teaching and learning have focused on the role of Edmodo in teaching writing and attitudes of students towards its usage. Purnawarman, Susilawati and Sundayana (2016), in their qualitative study, investigated the role of Edmodo in teaching writing in a blended learning setting. Sample size of his study was 17 students. Researcher found that Edmodo easily made students to write interactively and meaningfully, it allowed students to work independently within group and to regard quality of their writing. Edmodo provided learning situation and guided students to consider Edmodo as a part of learning.

In her study on 42 participants, Al-Kathiri (2014) investigated the effect of Edmodo in Saudi secondary school on EFL instruction, attitudes, and challenges. She conducted an experimental quantitative study. She pointed to high positive attitudes of students towards Edmodo. Edmodo assisted learners to overcome isolation. Students faced with challenges including the small-sized screen and slow-speed internet.

Ali (2015) investigated the experiences and attitudes of tertiary students towards using Edmodo in language learning. The researcher selected 24 students based on purposive sampling. The results showed that face-to-face discussion could not be replaced by online platform; students experienced different feeling regarding use of Edmodo in language classroom.

Pop (2013) explored Edmodo e-portfolios in EFL and 37 participants took part in this qualitative study. Participation showed high satisfaction towards use of Edmodo in their language learning because they could share their ideas. Edmodo offered "effective monitoring and timely guiding, the possibility to customize activities according to proficiency level as well as to maximize all the students' learning time by offering them a safe platform where to continue to practice the target language" (Pop, 2013, p.341).

In their quasi-experimental study, Shams-Abadi, Ahmadi and Mehrdad (2015) concluded that Edmodo effectively influenced on their writing performance when learners utilized it. Sample size was 40 female students. Bicen (2015) also focused on the role of Edmodo in mobile assisted language learning. The results showed the significant effect of Edmodo on students' foreign language learning, success, communication, having an entertaining learning environment.

\subsection{WhatsApp (2009)}

The literature on the effectiveness of WhatsApp on language learning suggested that WhatsApp could facilitate learning vocabulary. Ashiyan and Salehi (2016a) did an experimental study to compare male and female in learning English 
collocation via WhatsApp. They pointed to the role of WhatsApp as an effective tool for improving collocation learning, they also mentioned no significant difference between male and female in using telegram for learning collocation. Ashiyan and Salehi (2016b), in their experimental study, investigated the effect of WhatsApp on learning and retention of collocation knowledge. The sample size was 60 participants. They concluded that WhatsApp could facilitate learning and retention of collocation.

Han and Keskin (2016) conducted a mixed research study to investigate the effect of WhatsApp on decreasing EFL speaking anxiety. The sample size was 39 participants. They found that learners experienced low level of anxiety in speaking when they used WhatsApp. Alsaleem (2013) examined whether "WhatsApp" electronic dialogue journaling have impact on writing vocabulary word choice and voice of EFL students. In so doing, the author did a quasi-experimental study. Thirty EFL students participated in this study. The results indicated significant difference between pretest and posttest. The results also showed that WhatsApp is an effective instrument in promoting specific skills of voice and vocabulary word choice.

In their experimental study, Jafari and Chalak (2016) investigated the effect of WhatsApp on teaching vocabulary to junior high school students. Sixty participants took part in this study. They found that WhatsApp has a significant effect on learning vocabulary. No significant difference was found between both genders considering vocabulary knowledge. Şahan, Çoban, and Razı (2016), in their mixed study, investigated learning English idioms through WhatsApp. They also found that WhatsApp can help students to learn English.

Samaie, Mansouri Nejad and Qaracholloo (2018), in their mixed study, investigated the effect of WhatsApp on self and peer assessments of oral language proficiency. Thirty participants took part in this study. They pointed out negative attitudes of learners towards assessment through WhatsApp. Moreover, WhatsApp did not play a significant role in self and peerassessment.

3.12 Storify (2010)

We found only one empirical study that actually examined the impact of Storify on language teaching and learning. Laire, Casteleyn and Mottart (2012) stated that very little attention has been paid to using social media for language teaching in general and writing instruction in particular. The effect of Storify on writing activities within classroom formed the central focus of a qualitative study. Eighty students participated in their study. Authors found that instruction via social media have influence on learners' writing process; they also pointed to the positive effect of Storify on learning engagement and process. This social network provided an opportunity for students to review and to revise their own and peers' writing.

3.13 Instagram (2010)

Empirical evidence for the effect of Instagram is limited to an action research. AL-Ali (2014) reported an action research study to examine use of Instagram in writing performance in ESL classroom. The results indicated that students gradually showed eagerness to use Instagram in their writing, and Instagram redefined teaching and created a more personalized learning experience.

3.14 Telegram (2013)

In the field of language learning, Iranian students and teachers use telegram as one of the most common social network to improve language proficiency. Mahshid and Kaviani (2016) did a quantitative experimental research to investigate the effect of telegram on teaching English vocabulary; 50 female EFL learners took part in their study. They found learning through telegram has significant impact on vocabulary learning progress.

Mahshidi and Kaviani (2016) investigated the effect of Telegram on learning English vocabularies and quantitative experimental study. The small size was 60 Iranian intermediate EFL learners. Experimental group outperformed control group, because experimental group learned vocabularies via telegram.

In their quantitative experimental study, Ghaemi and Golshan (2017) examined the effect of telegram on teaching English vocabulary. Sixty participants took part in this study. They concluded that telegram has a positive effect on vocabulary learning. Rassouli and Biria (2017) found that participants developed meaningful interaction and communication through telegram.

Setiawan and Wahyuni (2017) investigated E-talk Castel's model (English talk class based telegram). The results showed that speaking ability of students improved through English talk based telegram. In his experimental study, Xodabande (2017) explored the role of telegram in teaching English language pronunciation to Iranian EFL learners. He concluded that use of telegram had a significant effect on improvement pronunciation. The sample size was 30 participants.

The limitations of the studies reviewed here are shown in Table 2 (see Appendix A). In fact, small size, proficiency level, unequal number of males and females are the common limitations of these studies.

\section{Comparing the Studies Based on the Context}

The findings of Iranian studies regarding the effect of SNSs on language teaching and learning are compared with the findings obtained from the international studies in this field. For more clarity, we categorized the reviewed studies based on the study context in Table 3 and Table 4 (See Appendix A). About 22 international publications were related to the effect of Facebook on language teaching and learning, 4 to 6 studies were conducted for each SNS including WhatsApp, Twiter, Youtube, Skype, Edmodo. One study was carried out for each SNS including Reddit, instagram, Storify, Telegram, Qzone, QQ. There are foreign publications on QQ, Skype, Facebook, Qzone, Reddit, Youtube, Twitter, Tumbler, Livemoca, Edmodo, Storify and Instagram. Iranian publications focused on a limited number of social media including Telegram and 
Instagram. Most international studies used mixed method, but Iranian studies employed experimental methods. Iranian studies investigated the effect of SNS on learning collocation, self and peer assessment, learners' attitudes, discussion, speaking anxiety, interaction, and vocabularies. However, international publications increased the scope of research on this area. They sought the influence of SNS on listening comprehension, writing performance, speaking, self-regulated learning, motivation, autonomous, confidence, teachers and learners' perspectives, interaction and feedback.

\section{Discussion and Conclusion}

Previous studies evaluating different SNSs observed consistent results on whether SNSs play a significant role in language teaching and learning. In this study, Wei (2012) and Li (2016) found that QQ improved learners' writing performance. Facebook played a significant role in learning language skills, confidence, motivation and attitudes (Kanilan, Ahmad \& Abidin, 2010), in improving writing performance (Shih, 2011); in increasing students' motivation for doing their writing assignment (Buga, Căpeneaţă, Chirasnel \& Popa 2014; Binti Shukor \& Noordin, 2014). Facebook also increased autonomous, competence and social relationship among learners (Akbari, Pilot and Simons, 2015); involvement and engagement (Lai, Wang, Li \& Hu, 2016); critical learning, vocabulary knowledge and confidence (Faryadi; 2017); motivation, self-confidence and positive attitudes (Kasuma, 2017; Özdemir, 2017). Qzone had significant impact on peer feedback (Xianwei, Asmawi \& Samuel, 2017). Reddit made learning English fun for children (York \& Stiller, 2013). Youtube had a positive impact on listening comprehension and increased the opportunity to communicate with native speakers (Kuo, 2009); YouTube was an important teaching resource (Alwehaibi, 2015); it also increased independence, autonomy and confidence in learning process (Chen, 2013).

Twitter enhanced regular learning routines, motivation and self-regulated learning (Sekiguchi, 2012); the degree of communication and interaction, noticing, meaning negotiation between students and native speakers (Hattem \& Lomicka, 2016). In addition, it reduced anxiety and increased confidence and corrective feedback on writing (de Larreta-Azelain, 2013); moreover, it increased involvement in peer to peer, more positive feedback than corrective feedback, noticing mistakes and corrective feedback (Perez-Sabaterand Montero-Fleta, 2015); involvement in negotiation meaning (AntenosCorforti, 2009; Hattem, 2012); vocabulary learning (Al-Dawood, 2013). Tumbler promoted students' writing skills and their motivation; it assisted them to receive feedbacks (Yunus \& Salehi, 2012). Livemocha increased peer feedback, autonomy, interaction and motivation (Jee \& Park, 2009). Lin, Warschauer and Blake (2016) referred to the positive attitudes towards usage and progress language learning through social networks such as Livemocha. Edmodo facilitated writing interactively and meaningfully (Purnawarman, Susilawati \& Sundayana, 2016; Shams-Abadi, Ahmadi \& Mehrdad, 2015).

WhatsApp promoted learning English collocation and facilitated learning and retention of collocation (Ashiyan \& Salehi 2016). It decreased EFL speaking anxiety and it is an effective instrument in promoting specific skills of voice and vocabulary word choice, idioms, vocabulary learning, interactions and experiences outside and inside the classroom; self and peer assessments of oral language proficiency. (Han \& Keskin, 2016; Alsaleem, 2013; Jafari \& Chalak, 2016; Şahan, Çoban \& Raz1, 2016; Samaie, Mansouri Nejad \& Qaracholloo, 2018). Storify helped learners to improve writing process; it also had positive effect on learning engagement and process (Laire, Casteleyn \& Mottart, 2012). Instagram encouraged students to write redefined teaching and created a more personalized learning experience (AL-Ali, 2014). Telegram played an important role in vocabulary learning (Mahshid \& Kaviani, 2016; Ghaemi \& Golshan, 2017); in promoting meaningful interaction and communication (Rassouli \& Biria, 2017); in improving English talk and pronunciation (Setiawan \& Wahyuni, 2017; Xodabande, 2017).

These results are very encouraging. One of the undeniable issues that emerges from these findings is the effect of SNSs on language teaching and learning. These studies support that learners enjoy using social media in English learning and teachers facilitate their teaching and participants' learning. However, most research has concentrated on its visibility for supporting language learning; very few empirical studies investigate the role of social media in four skills of language learning. The evidence of efficacy for social media on reading, listening, speaking, writing, and assessment of these four skills is limited. Iranian researchers focused on the effect of social media including Telegram and WhatsApp on language learning. Filtering may be one of the reasons why the Iranian researchers focused on two social media tools. Limited sample sizes, convenience samples of existing classes, lack of control group, time limitation, proficiency level and the way of sampling are limitations of some empirical studies. Among those social media tools that were included in this review, less evidence was found for Storify, Tumbler, Reditt, QQ, Qzone, Telegram and Instagram. The findings have important implications for developing teaching and learning methods inside and outside of classroom. Furthermore Iranian body of research should be undertaken to investigate language teaching and learning via SNSs including Baidu Tieba, Facebook, Gab, Google+, Myspace, Instagram, LinkedIn, Pinterest, Tumblr, Twitter, Viber, VK, Weibo, WhatsApp, Wikia, Snapchat, Friendster, and YouTube. 


\section{References}

Akbari, E., Naderi, A., Simons, R. J., \& Pilot, A. (2016). Student Engagement and Foreign Language Learning Through Online Social Networks. Asian-Pacific Journal of Second and Foreign Language Education, 1, 1-22.

Akbari, E., Pilot, A., \& Simons, P. R. J. (2015). Autonomy, Competence, and Relatedness In Foreign Language Learning Through Facebook. Computers in Human Behavior, 48, 126-134.

Akbari, E., Simons, P. R. J., Pilot, A., \& Naderi, A. (2017). Peer Feedback in Learning A Foreign Language in Facebook. Global Journal of Human Social Science, 17, 31-44.

Al-Ali, S. (2014). Embracing the Selfie Craze: Exploring the Possible Use of Instagram as a Language M-Learning Tool. Issues and Trends in Educational Technology, 2.

Albaddi, M. A. (2013). Teachers' Perceptions Of Youtube as a Potential Learning Resource for English Education in Libya. Published $\mathrm{PhD}$ thesis, Southern Illinois University, Carbondale.

Al-Dawood, M. M. N. (2013). Tweet, Share and Learn; the Effect of Micro-Blogging on Twitter on the Vocabulary Improvement of Saudi Female EFL College Students. Published PhD thesis, King Saud University, Riyadh, Saudi Arabi.

Ali, Z. (2015). A Case Study of Tertiary Students' Experiences Using Edmodo in Language Learning. International Journal of Language Education and Applied Linguistics (IJLEAL), 2, 39-48.

Al-Kathiri, F. (2014). Beyond the Classroom Walls: Edmodo in Saudi Secondary School EFL Instruction, Attitudes and Challenges. English Language Teaching, 8, 189-204.

Alsaleem, B. I. A. (2013). The Effect of" Whatsapp" Electronic Dialogue Journaling on Improving Writing Vocabulary Word Choice and Voice Of EFL Undergraduate Saudi Students. Arab World English Journal, 4, 213-225.

Alwehaibi, H. O. (2015). The Impact of Using Youtube in EFL Classroom on Enhancing EFL Students' Content Learning. Journal of College Teaching and Learning (Online), 12, 121-126.

Ashiyan, Z. \& Salehi, H. (2016a). A Comparison of Male And Female Learners' English Collocation Learning through Using Whatsapp. International Journal, 6. 25-42.

Ashiyan, Z., \& Salehi, H. (2016b). Impact of Whatsapp on Learning And Retention of Collocation Knowledge among Iranian EFL Learners. Advances in Language and Literary Studies, 7, 112-127.

Aydin, S. (2014). Foreign Language Learners' Interactions with Their Teachers on Facebook. System, 42, $155-163$.

Balasubramanian, K., Jaykumar, V., \& Fukey, L. N. (2014). A Study on "Student Preference towards the Use of Edmodo as a Learning Platform to Create Responsible Learning Environment”. Procedia-Social and Behavioral Sciences, 144, 416422.

Baґ̈z, T. (2016). Pre-Service EFL Teacher's Attitudes towards Language Learning Through Social Media. Procedia-Social and Behavioral Sciences, 232, 430-438.

Beltrán, C. I. (2009). The Use Of Skype ${ }^{\text {TM }}$ Chat For Improving Writing Skills in an A2 Adult Learners Group. Unpublished MA thesis in English Language Teaching-Autonomous Learning Environments, Universidad de la Sabana, Chía, Colombia.

Bicen, H. (2015). The Role of Social Learning Networks in Mobile Assisted Language Learning: Edmodo as a Case Study. J. UCS, 21, 1297-1306.

Binti Shukor, S. S., \& Noordin, N. (2014). Effects of Facebook Collaborative Writing Groups on ESL Undergraduates' Writing Performance. International Journal of English Language Education, 2, 89-99.

Blankenship, R., \& Kim, D. (2012). Revealing Authentic Teacher Professional Development Using Situated Learning in Virtual Environments as a Teaching Tool. In International Forum of Teaching and Studies, 8, 36-53.

Blattner, G., \& Fiori, M. (2009). Facebook in the Language Classroom: Promises and Possibilities. International Journal of Instructional Technology and Distance Learning, 6, 17-28.

Bray, E., \& Iswanti, S. N. (2013). Japan-Indonesia Intercultural Exchange in a Facebook Group. The Language Teacher, 37, 29-34.

Brick, B. (2013). Learning Language via Social Networking Sites. Pedagogical Considerations and Opportunities for Teaching and Learning On The Web, 1.University of Central Lankashire, Uk.

Buga, R., Căpeneaţă, I., Chirasnel, C., \& Popa, A. (2014). Facebook in Foreign Language Teaching-A Tool to Improve Communication Competences. Procedia-Social and Behavioral Sciences, 128, 93-98.

Cardoso, T., \& Matos, F. (2012). Learning Foreign Languages in The Twenty-First Century: An Innovating Teletandem Experiment through Skype. In Media in Education, 87-95. Springer, New York, NY.

Chen, S., Lin, L., \& Yuan, X. (2017). Social Media Visual Analytics. In Computer Graphics Forum , 36, $563-587$.

Chen, Y. (2013). The Possibility of Applying Youtube to Motivate Learning Autonomy. Journal of International Education Research, 9, 207-216.

De Larreta-Azelain, M. D. C. (2013). Learner's Attitudes toward Collaborative Writing in E-Language Learning Classes: A Twitter Project for German as a Foreign Language. Revista española de lingüistica aplicada, 26, 127-138.

Ellison, N. B. (2007). Social Network Sites: Definition, History, and Scholarship. Journal of Computer-Mediated Communication, 13, 210-230.

Eren, Ö. (2012). Students' Attitudes towards Using Social Networking in Foreign Language Classes: A Facebook Example. Public Relations Journal, 4, 288-294. 
Faryadi, Q. (2017). Effectiveness of Facebook in English Language Learning: A Case Study. Open Access Library Journal, 4, 1-11.

Ghaemi, F. \& Golshan, N.S., (2017). The Impact of Telegram as a Social Network on Teaching English Vocabulary among Iranian Intermediate EFL Learners. International Journal of Media and Communication, 1, 23-29.

Golonka, E. M., Bowles, A. R., Frank, V. M., Richardson, D. L., and Freynik, S. (2014). Technologies for Foreign Language Learning: A Review of Technology Types and Their Effectiveness. Computer assisted language learning, 27, 70-105.

Han, T., \& Keskin, F. (2016). Using a Mobile Application (Whatsapp) to Reduce EFL Speaking Anxiety. Gist Education and Learning Research Journal, 12, 29-50.

Hattem, D., \& Lomicka, L. (2016). What the Tweets Say: A Critical Analysis of Twitter Research in Language Learning from 2009 to 2016. E-Learning and Digital Media, 13, 5-23.

Hirotani, M., \& Fujii, K. (2015). The Integration of a Three-Year-Long Intercultural Collaborative Project into a Foreign Language Classroom for The Development Of Intercultural Competence. In Critical CALL-Proceedings of the 2015 EUROCALL Conference, Padova, Italy, 235-242.

Istifci, I. (2014). Perceptions of EFL Students on Educational Use of Facebook. In Proceedings of the European Conference on social media: ECSM 2014, 219-225.

Jafari, S., \& Chalak, A. (2016). The Role of Whatsapp in Teaching Vocabulary to Iranian EFL Learners at Junior High School. English Language Teaching, 9, 85-92.

Jee, M. J., \& Park, M. J. (2009). Livemocha as an Online Language-Learning Community. Calico Journal, 26, 448-456.

Jin, S. (2015). Using Facebook to Promote Korean EFL Learners' Intercultural Competence. Language Learning \& Technology, 19, 38-51.

Kabilan, M. K., Ahmad, N., \& Abidin, M. J. Z. (2010). Facebook: An Online Environment for Learning Of English in Institutions of Higher Education?. The Internet and higher education, 13, 179-187.

Kanasin, T. (2014). Utilizing Facebook to teach Thai EFL students' writing skills: A case study.

Kasuma, S. A. A. (2017). Using Facebook for English Language Learning: the Differences Among Gender and Ethnicity. Journal of Nusantara Studies (JONUS), 2, 177-193.

Kotula, K. (2016). Teaching a Foreign Language in a Desktop Videoconferencing Environment. Teaching English with Technology, 16, 37-51.

Kuo, L. L. (2009). The Effects of Youtube Listening/Viewing Activities on Taiwanese EFL Learners' Listening Comprehension. La Sierra University, California, United States.

Lai, C. (2015). Modeling Teachers' Influence on Learners' Self-Directed Use of Technology For Language Learning outside The Classroom. Computers and Education, 82, 74-83.

Lai, C., Wang, Q., Li, X., \& Hu, X. (2016). The Influence of Individual Espoused Cultural Values on Self-Directed Use of Technology for Language Learning beyond the Classroom. Computers in Human Behavior, 62, 676-688.

Laire, D., Casteleyn, J., \& Mottart, A. (2012). Social Media's Learning Outcomes within Writing Instruction in the EFL Classroom: Exploring, Implementing and Analyzing Storify. Procedia-Social and Behavioral Sciences, 69, $442-448$.

Lantz-Andersson, A., Vigmo, S., \& Bowen, R. (2013). Crossing Boundaries in Facebook: Students' Framing of Language Learning Activities as Extended Spaces. International Journal of Computer-Supported Collaborative Learning, 8, 293312.

Levak, N., and Son, J. B. (2017). Facilitating Second Language Learners' Listening Comprehension with Second Life and Skype. ReCALL, 29, 200-218.

Lewandowski, M. (2015). Creating Virtual Classrooms (Using Google Hangouts) for Improving Language Competency. Language Issues: The ESOL Journal, 26, 37-42.

Li, L. (2016). Effects of Text-Based QQ Communication on Medical College Student's English Writing. Theory and Practice in Language Studies, 6, 1971-1981.

Lin, C. H., Warschauer, M., \& Blake, R. (2016). Language Learning Through Social Networks: Perceptions and Reality, Language Learning \& Technology, 20, 124-147.

Lord, G., \& Lomicka, L. (2014). Twitter as a Tool to Promote Community Among Language Teachers. Journal of Technology and Teacher Education, 22, 187-212.

Mashhadi, H. D., \& Kaviani, M. (2016). The Social Impact of Telegram as a Social Network on Teaching English Vocabulary among Iranian Intermediate EFL Learners (Payam Noor Center). SSYJ, 7, 65-76.

Meng, J., Martinez, L., Holmstrom, A., Chung, M., \& Cox, J. (2017). Research on Social Networking Sites and Social Support from 2004 to 2015: A Narrative Review and Directions For Future Research. Cyberpsychology, Behavior, and Social Networking, 20, 44-51.

Özdemir, E. (2017). Promoting EFL Learners' Intercultural Communication Effectiveness: A Focus on Facebook. Computer Assisted Language Learning, 30, 510-528.

Pegg, K. J., O'Donnell, A. W., Lala, G., and Barber, B. L. (2017). The Role of Online Social Identity in The Relationship between Alcohol-Related Content on Social Networking Sites and Adolescent Alcohol Use. Cyberpsychology, Behavior, and Social Networking, 21, 50-55. 
Pop, A. (2013). Edmodo e-portfolios in EFL-A Case Study. In 8th International Conference on Virtual Learning, In 8th International Conference on Virtual Learning, Romania, 25-26.

Purnawarman, P., Susilawati, S., \& Sundayana, W. (2016). The Use of Edmodo in Teaching Writing in a Blended Learning Setting. Indonesian Journal of Applied Linguistics, 5, 242-252.

Rassouli, M., \& Biria, R. (2017).The Conversation Analysis of Iranian EFL Learners' Interaction via Telegram Application. International Journal of English and Education, 2, 219-234.

Razak, N. A., Saeed, M., \& Ahmad, Z. (2013). Adopting Social Networking Sites (Snss) as Interactive Communities among English Foreign Language (EFL) Learners in Writing: Opportunities and Challenges. English Language Teaching, 6, 187- 198.

Romaña Correa, Y. (2015). Skype ${ }^{\text {TM }}$ Conference Calls: A Way to Promote Speaking Skills in the Teaching and Learning of English. Profile Issues in Teachers Professional Development, 17, 143-156.

Roy, D., Brine, J., \& Murasawa, F. (2016). Usability of English Note-Taking Applications in a Foreign Language Learning Context. Computer Assisted Language Learning, 29, 61-87.

Şahan, Ö., Çoban, M., \& Razı, S. (2016). Students Learn English Idioms through Whatsapp: Extensive Use of Smartphones. Erzincan Üniversitesi Ĕgitim Fakültesi Dergisi, 18, 1230-1251.

Samaie, M., Mansouri Nejad, A., \& Qaracholloo, M. (2018). An Inquiry Into the Efficiency Of Whatsapp for Self-And PeerAssessments of Oral Language Proficiency. British Journal of Educational Technology, 49, 111-126.

Saylag, R. (2013). Facebook as a Tool in Fostering EFL Teachers' Establishment of Interpersonal Relations with Students through Self-Disclosure. Procedia-Social and Behavioral Sciences, 82, 680-685.

Sekiguchi, S. (2012). Investigating the Effects of Twitter on Developing a Social Learning Environment to Support Japanese EFL Students' Self-Regulated Learning. In International Conference "ICT for Language learning” (1-5).

Setiawan, R. \& Wahyuni, N.C.(2017). English Talk Class Based Telegram (E-talk Castel): An Innovative and Creative Strategy to Stimulate Students' Speaking Skill. In English Language and Literature International Conference (ELLiC) Proceedings , 1, 195-199.

Seyyedrezaeia, S. H., Kazemib, Y., \& Shahhoseinic, F.(2016). Mobile Assisted Language Learning (MALL): An Accelerator to Iranian Language Learner's Vocabulary Learning Improvement. International Journal of research in Linguistics, language Teaching and Testing 1, 7-13.

Shams-Abadi, B. B., Ahmadi, S. D., \& Mehrdad, A. G. (2015). The Effect of Edmodo on EFL Learners ${ }^{\text {ee Writing }}$ Performance. International Journal of Educational Investigations, 2, 88-97.

Shen, L., \& Suwanthep, J. (2011). E-Learning Constructive Role Plays for EFL Learners in China's Tertiary Education. Asian EFL Journal, 49, 2-26.

Shih, R. C. (2011). Can Web 2.0 Technology Assist College Students in Learning English Writing? Integrating Facebook and Peer Assessment with Blended Learning. Australasian Journal of Educational Technology, 27, 829-845.

Sun, Y. (2014). Microteaching Writing On Youtube for Pre-Service Teacher Training: Lessons Learned. CALICO Journal, $31,179-200$.

Sun, Y. C., \& Yang, F. Y. (2015). I Help, Therefore, I Learn: Service Learning on Web 2.0 In An EFL Speaking Class. Computer Assisted Language Learning, 28, 202-219.

Suthiwartnarueput, T., \& Wasanasomsithi, P. (2012). Effects of Using Facebook as a Medium for Discussions of English Grammar and Writing of Low-Intermediate EFL Students. Electronic Journal of Foreign Language Teaching, 9, 194214.

Terhune, N. M. (2016). Language Learning Going Global: Linking Teachers and Learners Via Commercial Skype-Based CMC. Computer Assisted Language Learning, 29, 1071-1089.

Villafuerte, J., \& Romero, A. (2017). Learners' Attitudes toward Foreign Language Practice on Social Network Sites. Journal of Education and Learning, 6, 145-158.

Warner, C., \& Chen, H. I. (2017). Designing Talk in Social Networks: What Facebook Teaches about Conversation. Language Learning and Technology, 21, 121-138.

Wei, L. (2012). Construction of Seamless English Language Learning Cyberspace via Interactive Text Messaging Tool. Theory and Practice in Language Studies, 2, 1590- 1597.

Xianwei, G., Asmawi, A., \& Samuel, M. (2017). Critical Peer Feedback for Business English Writing through Qzone Blogs: A Mechanism Among Chinese Undergraduates. GEMA Online ${ }^{\circledR}$ Journal of Language Studies, 17, 39-54.

Xianwei, G., Samuel, M., \& Asmawi, A. (2016). Qzone Weblog for Critical Peer Feedback to Improve Business English Writing: A Case of Chinese Undergraduates. Turkish Online Journal of Educational Technology-TOJET, 15, 131-140.

Xodabande, I. (2017). The Effectiveness of Social Media Network Telegram in Teaching English Language Pronunciation to Iranian EFL Learners. Cogent Education, 4, 1-14.

Yang, P. L. (2013). Discourse Analysis of EFL College Learners' Online Social Interaction and Attitudes towards Facebook. International Journal of English Linguistics, 3, 64-72.

Yen, Y. C., Hou, H. T., \& Chang, K. E. (2013). Applying Skype in English as a Foreign Language Instruction: Effect on Students' Speaking Errors. In International Conference on Web-Based Learning, 312-319. Springer, Berlin, Heidelberg. 
Yen, Y. C., Hou, H. T., \& Chang, K. E. (2015). Applying Role-Playing Strategy to Enhance Learners' Writing and Speaking Skills in EFL Courses Using Facebook and Skype as Learning Tools: A Case Study in Taiwan. Computer Assisted Language Learning, 28, 383-406

York, J., \& Stiller, S. (2013). Comics, Crowdsourcing and Up-Votes: EFL on the Front Page of the Internet. JALT CALL Journal, 9, 99-112

Yunus, M., \& Salehi, H. (2012). Tumblr as a Medium to Improve Students' Writing Skills. Journal of Applied Sciences Research, 8, 383-389.

\section{Appendix A: Tables}

Table 1: Reviewed SNSs and their brief descriptions and effectiveness

\begin{tabular}{|c|c|c|}
\hline $\begin{array}{l}\text { SNS and its } \\
\text { production } \\
\text { date }\end{array}$ & Brief description & Effectiveness \\
\hline QQ (1999) & $\begin{array}{l}\text { Tancent QQ (known as QQ) is a Chinese } \\
\text { instant messaging software service. It } \\
\text { provides online social games, music, } \\
\text { shopping, microblogging, movies, group, } \\
\text { and voice chat software. }\end{array}$ & 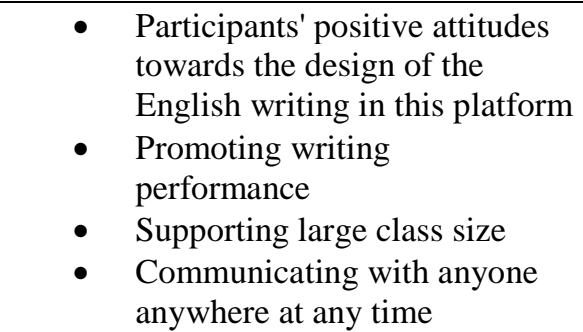 \\
\hline Skype (2003) & $\begin{array}{l}\text { Skype is a telecommunications' application } \\
\text { software for video chat. It provides instant } \\
\text { messaging services. Users can transmit both } \\
\text { text and video messages through Skype. } \\
\text { They also can exchange images and texts. }\end{array}$ & $\begin{array}{l}\text { - Facilitating listening } \\
\text { comprehension } \\
\text { - Increasing participation } \\
\text { - Improving speaking skills }\end{array}$ \\
\hline $\begin{array}{l}\text { Facebook } \\
(2004)\end{array}$ & $\begin{array}{l}\text { It is an American online social media and } \\
\text { social networking service. It makes } \\
\text { opportunities for people to communicate } \\
\text { with their family, friends, and coworkers. In } \\
\text { February 2004, Facebook was launched. It } \\
\text { was initially designed for Harvard College } \\
\text { students. }\end{array}$ & $\begin{array}{l}\text { - } \begin{array}{l}\text { Promoting daily } \\
\text { - }\end{array} \text { Creating spaces for autonomy } \\
\text { and engagement } \\
\text { - } \quad \text { Increasing motivation for } \\
\text { productive skills } \\
\text { - Making learning process fun } \\
\text { and easy }\end{array}$ \\
\hline $\begin{array}{l}\text { Qzone } \\
(2005)\end{array}$ & $\begin{array}{l}\text { It is a social networking website for writing } \\
\text { blogs, keeping diaries, sending photos, } \\
\text { listening to music and watching movies. }\end{array}$ & $\begin{array}{l}\text { A proper type of weblog for } \\
\text { online critical peer feedback }\end{array}$ \\
\hline $\begin{array}{l}\text { Reddit } \\
(2005)\end{array}$ & $\begin{array}{l}\text { It is an American social news aggregation, } \\
\text { web content rating, and discussion website } \\
\text { for sending content to the site such as links, } \\
\text { text posts, and images. }\end{array}$ & $\begin{array}{l}\text { - Helping learners post text- } \\
\text { based links known as self-post, } \\
\text { crowdsourcing, comic page for } \\
\text { enjoying learning and using } \\
\text { English. }\end{array}$ \\
\hline $\begin{array}{l}\text { YouTube } \\
(2006)\end{array}$ & $\begin{array}{l}\text { YouTube is an American video-sharing } \\
\text { website to upload, to view, and to share } \\
\text { information to other users. }\end{array}$ & $\begin{array}{l}\text { Use of video clip for listening } \\
\text { comprehension } \\
\text { - } \\
\text { - } \quad \text { Communication with native } \\
\text { speakers }\end{array}$ \\
\hline $\begin{array}{l}\text { Twitter } \\
(2006)\end{array}$ & $\begin{array}{l}\text { Online news and social networking in } \\
\text { which individuals can send and contact with } \\
\text { messages with } 140 \text { characters called as } \\
\text { tweets. Now, tweets can be } 280 \text { characters } \\
\text { for all languages except Japanese. }\end{array}$ & $\begin{array}{l}\text { - Having a beneficial effect on } \\
\text { pronunciation features } \\
\text { - } \quad \text { Providing corrective feedback } \\
\text { on writing } \\
\text { - } \quad \text { Reducing anxiety } \\
\text { - Increasing confidence } \\
\text { - Increasing vocabularies }\end{array}$ \\
\hline
\end{tabular}


Tumblr

Livemocha (2007)

Edmodo (2008)

WhatsApp (2009)

Storify

(2010)

Instagram (2010)

Telegram (2013)
A microblogging and social networking website help users send multimedia and other contents to a short form blog.

Livemocha, an online language learning community, supplies materials for instruction in 38 languages. It is a platform to communicate with each other for language learning. It uses the power of social networking for language learning.

This social learning platform facilitates communication and learning management. A classroom tool that makes safe and easy way to connect, to share content, and to access homework, grades and school notices.

It is a freeware and cross-platform instant messaging for sending and receiving test messages and voice calls, video calls, images.

It is a social network for creating stories or timelines using social media.

Instagram is a mobile desktop. It is also an internet-based photo-sharing application to share, upload photos and videos.

It is a non-profit cloud-based instant messaging service.
- Enhancing students' motivation

- Assessing learners to receive feedbacks

- $\quad$ Promoting writing skills by brainstorming, generating and sharing ideas

- Communication and interaction among learners in learning language skills

- More than 160 language learning material consisting of reading, writing, listening, and speaking exercises

- $\quad$ Posting speaking and writing exercises

- Creating and managing an online classroom community

- Working and communicating with classmates anywhere at anytime

- An effective tool for improving collocation learning

- $\quad$ Student-centered writing opportunities

- User generated content, creative production, autonomy

- Collaborative learning

- Promoting specific skills of voice and vocabulary word choice

- Redefining teaching

- More personalized learning experience

- Decreasing EFL speaking anxiety

- Having a significant impact on vocabulary learning progress

- Developing meaningful interaction and communication

- Improving speaking ability of students through English talk based telegram

- A significant effect on improvement of pronunciation

- Self and peer assessment 